\title{
Calcium supplementation reverts central adiposity, leptin, and insulin resistance in adult offspring programed by neonatal nicotine exposure
}

\author{
J L Nobre, P C Lisboa, A P Santos-Silva, N S Lima, A C Manhães, J F Nogueira-Neto, A Cabanelas, \\ C C Pazos-Moura ${ }^{1}$, E G Moura and E de Oliveira \\ Department of Physiological Sciences $-5^{\circ}$ andar, Roberto Alcantara Gomes Biology Institute, State University of Rio de Janeiro, Avenida 28 de setembro, 87 , \\ Rio de Janeiro, RJ 20551-030, Brazil \\ ${ }^{1}$ Laboratory of Molecular Endocrinology, Institute of Biophysics Carlos Chagas Filho, Federal University of Rio de Janeiro, Rio de Janeiro, RJ 21949-900, Brazil \\ (Correspondence should be addressed to E de Oliveira; Email: elainedeoliveir@pq.cnpq.br)
}

\begin{abstract}
Obesity is a worldwide epidemic. Calcium influences energy metabolism regulation, causing body weight loss. Because maternal nicotine exposure during lactation programs for obesity, hyperleptinemia, insulin resistance (IR), and hypothyroidism, we decided to evaluate the possible effect of dietary calcium supplementation on these endocrine dysfunctions in this experimental model. Osmotic minipumps containing nicotine solution $(\mathrm{N}: 6 \mathrm{mg} / \mathrm{kg}$ per day for 14 days) or saline $(\mathrm{C})$ were s.c. implanted in lactating rats 2 days after giving birth (P2). At P120, N and C offspring were subdivided into four groups: 1) $\mathrm{C}$ - standard diet; 2) C with calcium supplementation (CCa, $10 \mathrm{~g}$ calcium carbonate/kg rat chow); 3) $\mathrm{N}$ - standard diet; and 4) $\mathrm{N}$ with calcium supplementation $(\mathrm{NCa})$. Rats were killed at P180. As expected, $\mathrm{N}$ offspring showed higher visceral and total body fat, hyperleptinemia, lower hypothalamus leptin receptor
\end{abstract}

(OB-R) content, hyperinsulinemia, and higher IR index. Also, higher tyrosine hydroxylase $(\mathrm{TH})$ expression $(+51 \%)$, catecholamine content $(+37 \%)$, and serum 25-hydroxyvitamin $\mathrm{D}_{3}(+76 \%)$ were observed in $\mathrm{N}$ offspring. Dietary calcium supplementation reversed adiposity, hyperleptinemia, OB-R underexpression, IR, TH overexpression, and vitamin D. However, this supplementation did not reverse hypothyroidism. In NCa offspring, Sirt1 mRNA was lower in visceral fat $(-37 \%)$ and higher in liver $(+42 \%)$. In conclusion, dietary calcium supplementation seems to revert most of the metabolic syndrome parameters observed in adult offspring programed by maternal nicotine exposure during lactation. It is conceivable that the reduction in fat mass per se, induced by calcium therapy, is the main mechanism that leads to the increment of insulin action.

Journal of Endocrinology (2011) 210, 349-359

\section{Introduction}

According to the World Health Organization (WHO), obesity is considered a global epidemic surpassing malnutrition (Kosti \& Panagiotakos 2006, WHO. Obesity e overweight. http://www.who.int/dietphysicalactivity/childhood/en 2007). Obesity is associated to dyslipidemia, insulin resistance (IR), and hypertension, which play key roles in raising the morbidity and mortality rates in cardiovascular disease in adulthood (Schulze et al. 2004). In several cases, some of these alterations can simultaneously appear, a condition called metabolic syndrome, which presents central obesity and peripheral IR as the major components (Weiss et al. 2004).

Experimental and epidemiological studies show an association between exposure to nutritional or hormonal factors during critical periods of life (such as pregnancy and/or lactation) with the development of chronic diseases in adulthood, such as obesity and type 2 diabetes. This biological phenomenon is known as metabolic programming
(Barker 2003, Moura \& Passos 2005, de Moura et al. 2008). Exposure to environmental pollutants during perinatal life can lead to several changes in both the short and the long term, acting as endocrine disruptors (Newbold 2010). Smoking during pregnancy is a known risk factor for obesity in adult life (Blake et al. 2000, Bergmann et al. 2003, Goldani et al. 2007). Recently, we have found that maternal exposure to nicotine during lactation programs for obesity in adulthood, along with additional dysfunctions such as higher central adiposity, hyperleptinemia, IR and leptin resistance, and secondary hypothyroidism (Oliveira et al. 2009, de Oliveira et al. 2010). Maternal smoking increases catecholamine levels in the amniotic fluid (Divers et al. 1981). Recently, we have shown that maternal nicotine during lactation increased both leptin serum levels and catecholamine content in the adrenal gland of suckling pups (Oliveira et al. 2010); however, it is unknown whether catecholamine function is programed in the adult animal. It is suggested that this could happen, because in another model of programming by neonatal hyperleptinemia, the adrenal catecholamine content was 
higher after leptin administration and this primed those animals to develop hyperleptinemia and higher adrenal catecholamine content in adulthood (Trevenzoli et al. 2007).

It was shown that individuals who have poor calcium intake present higher body weight (BW; Zemel 2002). Furthermore, a calcium-rich diet is known to improve insulin sensitivity (Choi et al. 2005, Ma et al. 2006, Pittas et al. 2007) and lipid profile (Jacqmain et al. 2003, Reid et al. 2010). One of the hypotheses that may explain the beneficial effects of dietary calcium supplementation relies on the fact that calcium has the ability to modulate energy metabolism through calciotropic hormone concentrations: calcitriol (1,25-dihydroxyvitamin $\mathrm{D}(1,25(\mathrm{OH}) 2 \mathrm{D}))$ and parathyroid hormone (PTH; Zemel 2002). Vitamin D increases calcium uptake by the adipocyte, decreasing UCP activity, lipolysis, and apoptosis. With high-calcium ingestion, PTH and vitamin D levels are decreased and the opposite effects are reported for the adipocyte. A diet that is poor in calcium could inhibit lipolysis, stimulate lipogenesis, and decrease lipid oxidation. Thus, a calcium-rich diet could decrease these hormone concentrations, thus decreasing lipid storage (Zemel 2002, Xiaoyu et al. 2007). Another hypothesis is that calcium has the ability to form insoluble complexes with lipids in the intestine, increasing fecal excretion and decreasing their absorption, which reduces the available energy to the organism, contributing to its anti-obesity effect (Zemel 2005, Teegarden et al. 2008).

Considering that dietary calcium therapy could have a role in weight loss, this study was designed to test the possible beneficial effects of calcium supplementation in reversing some endocrine-metabolic changes, such as central adiposity, leptin and IR, and thyroid hypofunction, which have been previously detected in adult rat offspring whose mothers were exposed to nicotine during lactation. As catecholamine was affected in the suckling pups by maternal nicotine exposure, we also intend to evaluate catecholamine function in the adult animal, because both catecholamine and thyroid hormones affect body adiposity. In this study, we specifically studied the effects of dietary calcium supplementation in animals exposed to nicotine during the lactation period instead of during pregnancy, because there is a higher rate of smoking relapse among lactating women (McBride \& Pirie 1990). In addition, in order to have some insight into possible factors involved in priming mechanisms, we studied sirtuin 1 (SIRT1) expression, a class III histone/protein $\mathrm{NAD}^{+}$-dependent deacetylase that has been implicated in the regulation of energy homeostasis (Elliott \& Jirousek 2008, Liang et al. 2009) and that can also be suppressed by smoking (Rajendrasozhan et al. 2008). Furthermore, increased SIRT1 has been associated with lower adiposity and protection against dietinduced metabolic disorders (Banks et al. 2008, Pfluger et al. 2008). Therefore, we reasoned that SIRT1 expression may be altered by programming and/or calcium treatment, as we have previously reported for other programming models (Franco et al. 2010, Trotta et al. 2011).

\section{Materials and Methods}

Animal use and experimental procedures were approved by the Animal Care and Use Committee of the Biology Institute of the State University of Rio de Janeiro (CEA/189/2007 and CEA/015/2009), which based its analysis on the principles promulgated by the Brazilian Law no. 11.794/2008 (Marques et al. 2009). Wistar rats were kept in a temperature-controlled room $\left(25 \pm 1{ }^{\circ} \mathrm{C}\right)$ with artificial light-darkness cycles (lights on $0700 \mathrm{~h}$, lights off $1900 \mathrm{~h}$ ). Virgin female rats (3-monthold) were caged with male rats at the ratio of $3: 1$. After mating, each female rat was placed in an individual cage with free access to food and water until delivery.

\section{Experimental model of programming by maternal} nicotine exposure

In total, 2 days after giving birth, 20 lactating rats were randomly assigned to one of the following groups: nicotine $(\mathrm{N})-2$ days after giving birth (P2), ten dams were lightly anesthetized with thiopental to allow s.c. insertion of osmotic minipumps (Alzet, 2ML2, Los Angeles, CA, USA). Minipumps were filled with nicotine (NIC) free base diluted in $0.9 \% \mathrm{NaCl}$ so as to deliver a dose rate of $6 \mathrm{mg} / \mathrm{kg}$ per day for 14 days of lactation, as described previously (Oliveira et al. 2009). This dose produces plasma nicotine levels similar to those observed in moderate to heavy smokers, $\sim 25 \mathrm{ng} / \mathrm{ml}$ (Lichtensteiger et al. 1988). Control (C) - ten dams were implanted with osmotic minipumps containing saline solution only, which were used for the same period mentioned above. According to the manufacturer's recommendation, minipumps must be filled with the solution of interest (in our case, nicotine or saline) and immersed in saline for $24 \mathrm{~h}$ prior to implantation to release substances continuously and homogeneously thereafter, a procedure that resulted in the $\mathrm{P} 2$ implantation.

In general, pregnant rats produce $10-12$ pups. To avoid the influence of the litter size in the programming effect, we only used dams whose litter size was ten pups. At birth, to maximize lactation performance, litters were adjusted to six male pups per $\mathrm{N}$ or $\mathrm{C}$ dam.

\section{Dietary calcium supplementation}

We decided to start calcium supplementation at P120 to evaluate whether this substance has a role in reverting central adiposity, because we have previously shown that by P90 N offspring already present higher central obesity and BW (Oliveira et al. 2009). N and C offspring were subdivided into four groups ( $n=10$ offspring per group): 1) control (C) received standard rat chow; 2) control calcium (CCa) received standard rat chow supplemented with calcium carbonate (10 g/kg rat chow); 3) nicotine $(\mathrm{N})$ - received standard rat chow; and 4) nicotine calcium (NCa) - received standard rat chow supplemented with calcium carbonate. BW and food intake of the offspring were evaluated every 4 days. 
Calcium carbonate was added to the standard chow. The calcium-enriched diet provided twice the amount of calcium (in the form of calcium carbonate) that is recommended for rodents, which is $5 \mathrm{~g}$ calcium $/ \mathrm{kg}$ of chow (Reeves 1997). This amount is based on the recommendation of supplementation for humans, where values up to two times the recommended amount have no toxic effect. Calcium was supplemented from P120 to P180, at which time all rats were killed by quick decapitation, with no prior anesthesia because it affects hormone and lipid metabolism (Chen et al. 2002). Blood, hypothalamus, liver, adrenal gland, carcass, and visceral fat were excised and kept frozen $\left(-80^{\circ} \mathrm{C}\right)$. Calcemia was analyzed using colorimetric Biosystem commercial test kits. The metabolite 25-hydroxyvitamin $\mathrm{D}_{3}$ was measured using a monoclonal antibody immunoassay (Elecsys and Cobas immunoassay analyzers, Roche Diagnostics $\mathrm{GmbH}$ ), with a range of detection from 4 to $100 \mathrm{ng} / \mathrm{ml}$. This hormone is generally measured to determine the overall vitamin D status. All measurements were performed in one assay.

\section{Body composition}

Visceral fat mass (VFM) was quickly collected and weighed for evaluation of central adiposity - mesenteric, epididymal, and retroperitoneal (Toste et al. 2006a,b, Fagundes et al. 2007) - and data were expressed as g/100 g BW. Body fat content was determined by carcass analysis (Toste et al. 2006a,b, Fagundes et al. 2007). All rats were eviscerated; carcasses were weighed, autoclaved for $1 \mathrm{~h}$, and homogenized in distilled water (1:1). Homogenates were stored at $4{ }^{\circ} \mathrm{C}$ for analysis. Homogenates $(3 \mathrm{~g})$ were used to determine fat content gravimetrically. Samples were hydrolyzed in a shaking water bath at $70^{\circ} \mathrm{C}$ for $2 \mathrm{~h}$ with $30 \% \mathrm{KOH}$ and ethanol. The total fatty acids and nonesterified cholesterol were removed with three successive washings with petroleum ether. After drying overnight in vacuum, all tubes were weighed and data were expressed as $\mathrm{g}$ fat $/ 100 \mathrm{~g}$ carcass. The estimate of the subcutaneous fat was calculated by subtracting the visceral fat from the total fat.

\section{Hormonal determination by RIA}

Blood samples were centrifuged $\left(1500 \mathrm{~g} / 20 \mathrm{~min}\right.$ per $\left.4{ }^{\circ} \mathrm{C}\right)$ to obtain serum, which was kept at $-20{ }^{\circ} \mathrm{C}$ until assay. All measurements were performed in one assay and samples were analyzed in duplicate. Leptin was measured by specific RIA kit (Linco Research, St Charles, MO, USA) with a range of detection from 0.5 to $50 \mathrm{ng} / \mathrm{ml}$; the intra-assay variation was $2 \cdot 9 \%$. Insulin was determined using a RIA kit (ICN Pharmaceuticals, Inc., Orangeburg, NY, USA) with an assay sensitivity of $0 \cdot 1 \mathrm{ng} / \mathrm{ml}$ and an intra-assay variation of $4 \cdot 1 \%$. Adiponectin was measured by specific RIA kit (Linco Research) with an assay sensitivity of $0.5 \mathrm{ng} / \mathrm{ml}$ and an intra-assay variation of $7 \cdot 1 \%$. Thyroid hormones were determined with a commercial RIA kit (ICN Pharmaceuticals, Inc.) with assay sensitivities of $0 \cdot 045 \mathrm{ng} / \mathrm{dl}$ (free thyroxine $\left(\mathrm{fT}_{4}\right)$ ) and $0.06 \mathrm{pg} / \mathrm{ml}$ (total triiodothyronine $\left.\left(\mathrm{tT}_{3}\right)\right)$. Intra-assay variations were $2 \cdot 8 \%\left(\mathrm{fT}_{4}\right)$ and $3 \cdot 6 \%\left(\mathrm{tT}_{3}\right)$.

\section{Lipid profile evaluation}

Serum total cholesterol (TC), triglycerides (TG), and highdensity lipoprotein (HDL) were analyzed using Biosystem commercial test kits. Low-density lipoprotein cholesterol (LDL-C) and very low-density lipoprotein cholesterol (VLDL-C) were obtained using Friedewald calculations:

$$
\begin{aligned}
& \mathrm{LDL}-\mathrm{C}(\mathrm{mg} / \mathrm{dl})=(\mathrm{TC}-\mathrm{HDL}-\mathrm{C}-\mathrm{TG}) / 5 . \\
& \mathrm{VLDL}-\mathrm{C}(\mathrm{mg} / \mathrm{dl})=\mathrm{TG} / 5
\end{aligned}
$$

Castelli indexes I and II that correlate with atherogenicity were obtained using the following formulae:

Castelli index I = TC/HDL.

Castelli index II = LDL/HDL.

\section{Glycemia and insulin sensitivity measurement}

Blood glucose was determined from the tail vein of fasting rats using a glucometer, after fasting for $12 \mathrm{~h}$ (ACCU-CHEK Advantage; Roche Diagnostics).

To measure the insulin sensitivity, the IR index (IRI) was calculated as follows: fasting insulin $(\mathrm{mIU} / \mathrm{ml}) \times$ fasting glucose $(\mathrm{mmol} / \mathrm{l})$.

\section{Catecholamine assays}

Total catecholamine (adrenaline and noradrenaline) content in the adrenal medulla was measured by the trihydroxyindole fluorescence method (Trevenzoli et al. 2007). Left adrenal glands were homogenized in $500 \mu \mathrm{l} 10 \%$ acetic acid using an ultrasonic processor and centrifuged (10 $000 \boldsymbol{g}$ for $1 \mathrm{~min})$. To assay, $50 \mu \mathrm{l}$ supernatant fraction was mixed with $250 \mu \mathrm{l}$ $0.5 \mathrm{M}$ PBS ( $\mathrm{pH} 7 \cdot 0$ ) and $25 \mu \mathrm{l}$ potassium ferricyanide $(0.5 \%)$, followed by incubation $(20 \mathrm{~min})$. Reaction was stopped with $500 \mathrm{ml}$ ascorbic acid-10 M NaOH (1:19 proportion). Parameters of the fluorometer were $420 \mathrm{~nm}$ to excitation and $510 \mathrm{~nm}$ to emission. Results were obtained by plotting the values into a linear regression of the standard adrenaline curve. Data were expressed as mmol catecholamines and mmol catecholamines/mg gland. Protein concentration was determined by the Bradford method.

\section{Western blotting analysis for hypothalamic leptin receptor and adrenal tyrosine hydroxylase}

Hypothalamus was isolated using the coordinates established by the Atlas of Neuroanatomy: with Systems Organization and Case Correlations (Warner 2001). To obtain cell extracts, 

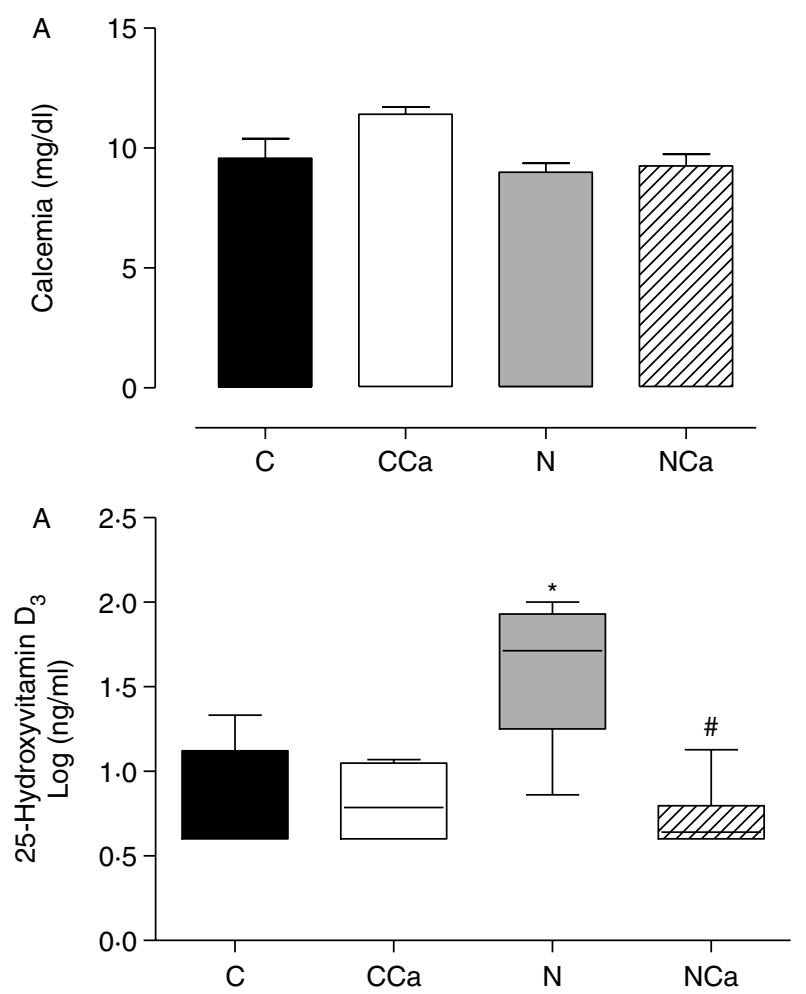

Figure 1 Calcemia (A) and 25-hydroxyvitamin $\mathrm{D}_{3}$ (B) of adult offspring whose mothers were exposed to nicotine or saline during lactation that were treated with dietary calcium supplement for 2 months. Values represent mean \pm S.E.M. of ten rats per group. ${ }^{*} P<0 \cdot 05$ versus control $(\mathrm{C}) ;{ }^{\sharp} P<0 \cdot 05$ versus nicotine $(\mathrm{N})$.

tissue was homogenized in ice-cold lysis buffer $(50 \mathrm{mM}$ HEPES, $1 \mathrm{mM} \mathrm{MgCl}_{2}, 10 \mathrm{mM}$ EDTA, Triton X-100 1\%, $\mathrm{pH}$ 6.4) containing the following protease inhibitors: $10 \mathrm{mg} / \mathrm{ml}$ aprotinin, $10 \mathrm{mg} / \mathrm{ml}$ leupeptin, $2 \mathrm{mg} / \mathrm{ml}$ pepstatin, and $1 \mathrm{mM}$ phenylmethylsulfonyl fluoride (Sigma-Aldrich) and centrifuged at $4{ }^{\circ} \mathrm{C}, 1120 \mathrm{~g}$ for $15 \mathrm{~min}$.

Because tyrosine hydroxylase $(\mathrm{TH})$ is an essential enzyme for catecholamine synthesizing pathway, its expression was measured in adrenal glands (Trevenzoli et al. 2007). Briefly, glands were homogenized in $1 \mathrm{ml} \mathrm{PBS}, \mathrm{pH} 7 \cdot 4$, containing $1 \mu \mathrm{l}$ protease inhibitors cocktail (aprotinin $1 \mathrm{mg} / \mathrm{ml}$, leupeptin $1 \mathrm{mg} / \mathrm{ml}$, and SBTI $1 \mathrm{mg} / \mathrm{ml}$ ) and centrifuged at $4{ }^{\circ} \mathrm{C}, 1120 \mathrm{~g}$ for $15 \mathrm{~min}$.

Total protein content in hypothalamus and adrenal homogenates was determined by the BCA protein kit assay (Thermo Scientific, Rockford, IL, USA), and cell lysates were denatured in sample buffer $(50 \mathrm{mM}$ Tris- $\mathrm{HCl}, \mathrm{pH} 6 \cdot 8$, $1 \%$ SDS, 5\% 2-mercaptoethanol, 10\% glycerol, and 0.001\% bromophenol blue) and heated at $95^{\circ} \mathrm{C}$ for $5 \mathrm{~min}$. Samples (hypothalamus: $30 \mathrm{mg}$ total protein; adrenal: $20 \mu \mathrm{g}$ total protein) were run in 10\% SDS-PAGE and electroblotted in a nitrocellulose membrane (Hybond P ECL membrane, Amersham Biosciences). Membranes were incubated with
TBS containing 5\% nonfat dry milk for 90 min to block nonspecific binding sites. Then, membranes were washed with TBS and incubated with primary antibody (polyclonal goat anti-leptin receptor (OB-R); Santa Cruz Biotechnology, Santa Cruz, CA, USA; monoclonal mouse anti-TH; SigmaAldrich) overnight at $4{ }^{\circ} \mathrm{C}(0.5 \%$ nonfat dry milk TBS diluted, 1:2000). Then, membranes were washed and incubated with secondary antibody (goat anti-mouse; Santa Cruz Biotechnology) conjugated with HRP $(0.5 \%$ nonfat dry milk TBS diluted, 1:2000) for $1 \mathrm{~h}$ at room temperature. Finally, OB-R and TH bands were visualized by chemiluminescent method (Kit ECL plus, Amersham Biosciences) followed by exposure to autoradiographic film (Hyperfilm ECL, Amersham Biosciences) for $5 \mathrm{~s}$. Results were normalized with actin. Area and density of the bands were quantified by Image J program (Media Cybernetics, Bethesda, Maryland, USA).

Leptin and SIRT1 expressions: reverse transcription-PCR analysis

Total RNA was isolated from white inguinal and epididymal adipose tissue explants and liver using commercially available kit and standard methodology (RNeasy lipid tissue mini kit, Qiagen and TRIZOL reagent, Invitrogen) respectively. For real-time PCR analysis, total RNA was reverse transcribed
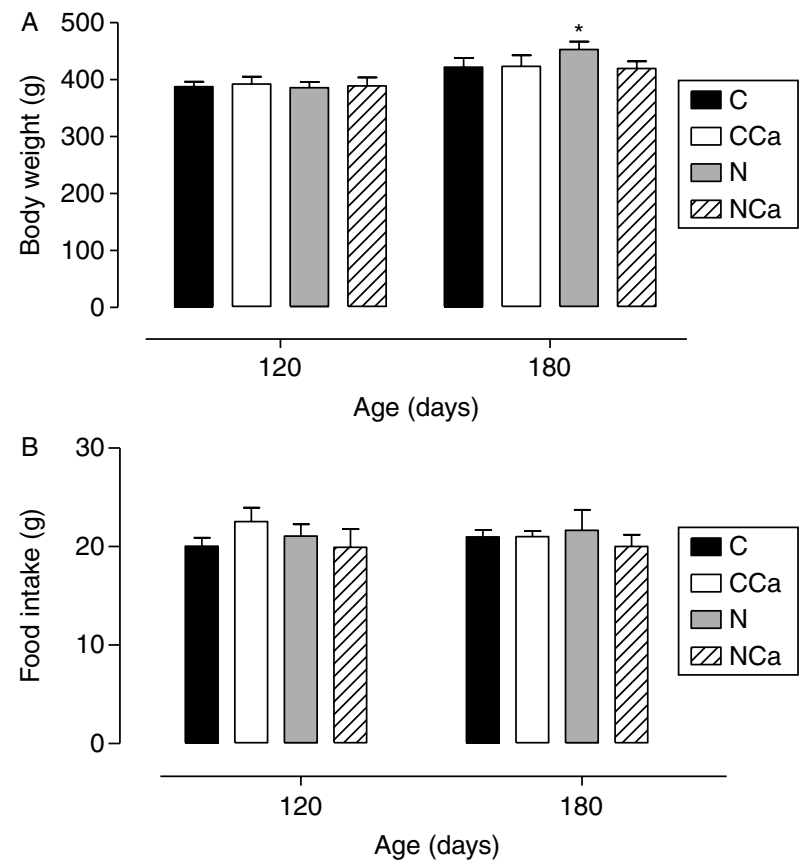

Figure 2 Body weight (A) and food intake (B) at 120 (first day of calcium supplementation) and 180 days old (killed) of $\mathrm{C}$ and $\mathrm{N}$ offspring treated with dietary calcium supplementation for 2 months (CCa and NCa). Values represent mean \pm S.E.M. of ten rats per group. $* P<0 \cdot 05$ versus control $(\mathrm{C})$. 


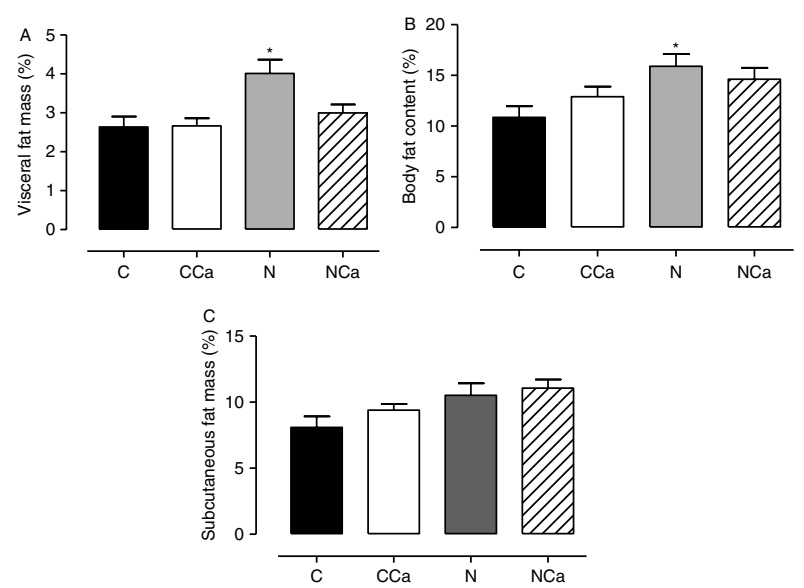

Figure 3 Visceral fat (A), total body fat (B), and subcutaneous fat (C) masses of adult offspring whose mothers were exposed to nicotine or saline during lactation that were treated with dietary calcium supplement for 2 months. Values represent mean \pm s.E.M. of ten rats per group. ${ }^{*} P<0 \cdot 05$ versus control (C).

using $1 \mu \mathrm{g}$ RNA for hepatic tissue and $500 \mathrm{ng}$ for adipose tissue using SuperScript III kit (Invitrogen).

The products were amplified on Applied Biosystems 7500 Real-Time PCR System (Life Technologies Co.) using SYBR Green PCR Master Mix (Applied Biosystems, Foster City, CA, USA) according to the recommendations of the manufacturer.

Leptin, SIRT1, and 36B4 cycle parameters were: $50^{\circ} \mathrm{C}$ for $2 \mathrm{~min}$ and $95^{\circ} \mathrm{C}$ for $10 \mathrm{~min}$, followed by 40 cycles at $95^{\circ} \mathrm{C}$ for $15 \mathrm{~s}, 60^{\circ} \mathrm{C}$ for $30 \mathrm{~s}$, and $70{ }^{\circ} \mathrm{C}$ for $45 \mathrm{~s}$. This final setup of the assay was defined after checking for product purity by analyses of melting curves and visualization of a single band of expected size in nusieve-agarose gel (4\%). In addition, appropriate cDNA serial curves were performed in order to confirm that the efficiency of the reaction was $\sim 1$. Changes in mRNA expression were calculated from the cycle threshold $\left(C_{\mathrm{t}}\right)$, after correcting for $36 \mathrm{~B} 4$, a ribosomal protein used as control and that did not show variations with the treatments (Akamine et al. 2007). Data are expressed as fold induction over control group, which was set to 1 .

The primer sequences were as follows: leptin forward $5^{\prime}$-CAT CTG CTG GCC TTC TCC AA- $3^{\prime}$ and reverse 5'-ATC CAG GCT CTC TGG CTT CTG-3', SIRT1 forward $5^{\prime}$-CAG GTT GCA GGA ATC CAA A-3' and reverse $5^{\prime}$-CAA ATC AGG CAA GAT GCT GT- $3^{\prime}$ and 36B4 forward $5^{\prime}$-CCG AGG CAA CAG TTG GGT A-3' and reverse $5^{\prime}$-TGT TTG ACA ACG GCA GCA TTT-3' (Rodgers et al. 2005, Machado et al. 2009, Paula et al. 2010).

\section{Mitochondrial $\alpha$-glycerol-3-phosphate dehydrogenase activity}

Liver $\boldsymbol{\alpha}$-glycerol-3-phosphate dehydrogenase (GPD) activity, a TH-dependent enzyme considered a marker of thyroid status, was measured in the mitochondrial fraction using phenazine methosulfate (PMS) as an electron transporter between the reduced enzyme and the iodonitrotetrazolium chloride violet (INT; Oliveira et al. 2007). Assay was performed in the presence of $0 \cdot 1 \mathrm{M} \mathrm{DL}-\alpha$ glycerophosphate diluted in KCN/KPB and a solution of $7.9 \mathrm{mM}$ INT to $0 \cdot 12 \mathrm{mM}$ PMS. Samples were analyzed at $500 \mathrm{~nm}$ in a spectrophotometer (TU-180, UV-VIS, Beijing Purkinje General Instrument, Haidian, Beijing, China) and the values were expressed as absorbance (O.D)/mg of mitochondrial protein. Protein was measured using the Bradford method (1976).

\section{Statistical analysis}

Results are reported as mean \pm s.E.M. The GraphPad Prism 5 was used for statistical analyses and graphics (GraphPad Software, Inc., La Jolla, CA, USA). The experimental data were analyzed by two-way ANOVA and NewmanKeuls multiple comparison tests. 25-Hydroxyvitamin $\mathrm{D}_{3}$ data were $\log$ transformed due to variance heterogeneity. The significance level was set at $P<0 \cdot 05$.

\section{Results}

Calcium supplementation for 2 months did not alter any of the parameters evaluated in the adult $\mathrm{C}$ offspring, such as BW, adiposity, serum leptin, Ob-R, serum insulin, and blood glucose. In addition, calcemia was not different among all groups (Fig. 1A), but serum concentration of 25-hydroxyvitamin $\mathrm{D}_{3}$ was higher $(+76 \%, P<0 \cdot 05$; Fig. 1B)
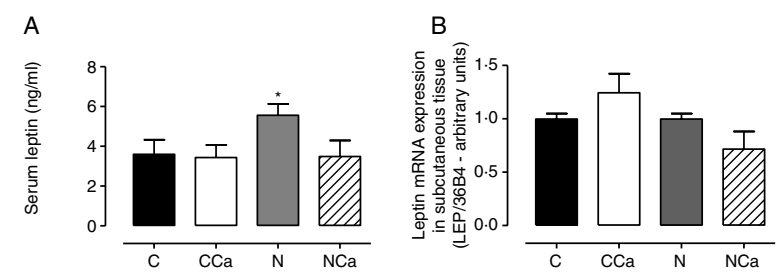

$\mathrm{C}$

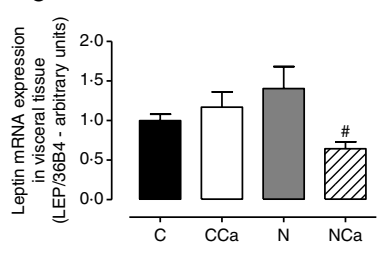

$\mathrm{D}$

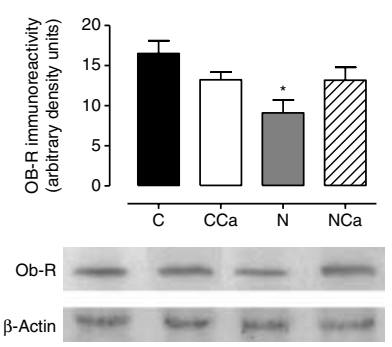

Figure 4 Serum leptin $(A)$, leptin mRNA expression in subcutaneous (B) and visceral (C) adipose tissue, and hypothalamic OB-R protein expression (D) of adult offspring whose mothers were exposed to nicotine or saline during lactation that were treated with dietary calcium supplement for 2 months. Values represent mean \pm s.E.M. of ten rats per group. ${ }^{*} P<0.05$ versus control $(C) ;{ }^{*} P<0.05$ versus nicotine $(\mathrm{N})$. 

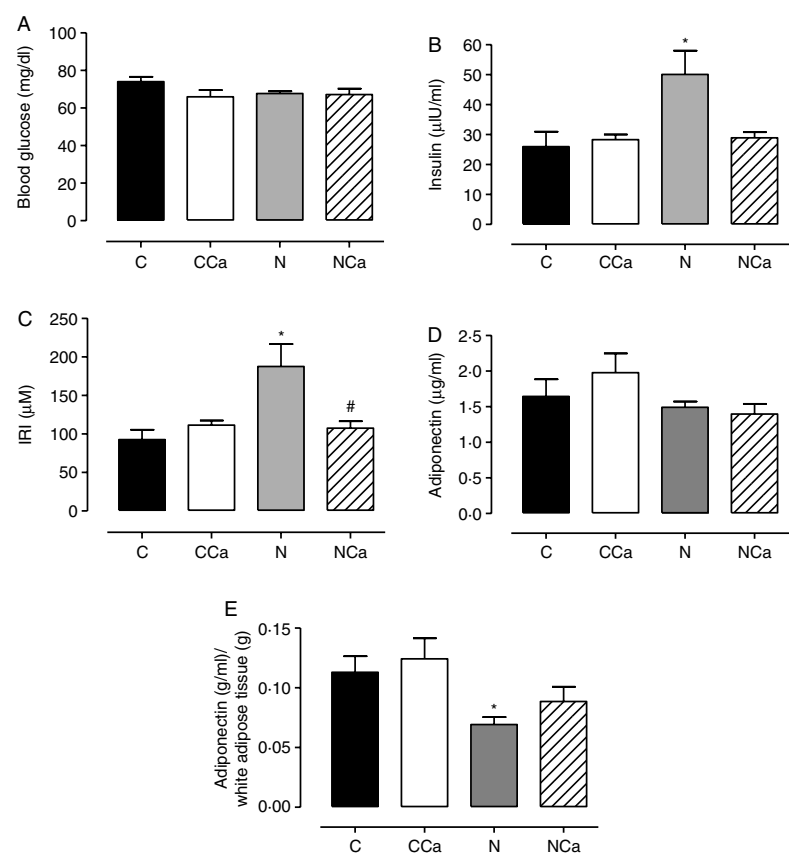

Figure 5 Glycemia (A), insulinemia (B), IRI (C), adiponectinemia (D), and adiponectin/visceral fat ratio (E) of adult offspring whose mothers were exposed to nicotine or saline during lactation that were treated with dietary calcium supplement for 2 months. Values represent mean \pm S.E.M. of ten rats per group. ${ }^{*} P<0 \cdot 05$ versus control (C); ${ }^{\#} P<0 \cdot 05$ versus nicotine $(N)$. IRI, Insulin resistance index.

in nicotine group and it was reduced by calcium supplementation $(-55 \%, P<0 \cdot 05$; Fig. $1 \mathrm{~A})$.

There was no significant difference in food intake before or after calcium supplementation between groups. $\mathrm{N}$ offspring presented higher BW at $\mathrm{P} 180(+7 \%, P<0 \cdot 05$; Fig. $2 \mathrm{~A})$. As expected, P180 $\mathrm{N}$ offspring showed higher visceral and total body fat content $(+53$ and $+45 \%$ respectively, $P<0 \cdot 05$; Fig. 3A and B), hyperleptinemia ( $+54 \%, P<0 \cdot 05$; Fig. 4A), and lower hypothalamic Ob-R content $(-45 \%, P<0 \cdot 05$; Fig. 4D). However, no difference in subcutaneous fat (Fig. 3C) was observed. As NCa offspring showed no difference from controls ( $\mathrm{C}$ and $\mathrm{CCa}$ ), calcium supplementation for 2 months normalized BW, visceral obesity, leptinemia, and hypothalamic $\mathrm{Ob}-\mathrm{R}$ content in $\mathrm{N}$ offspring. Leptin mRNA expression was not significantly changed in the subcutaneous adipose tissue in all groups (Fig. 4B). However, NCa offspring had lower leptin mRNA expression in the visceral adipose tissue $(-55 \%, P<0 \cdot 05$; Fig. 4C) compared with the $\mathrm{N}$ group.

$\mathrm{N}$ offspring displayed normoglycemia (Fig. 5A), hyperinsulinemia ( $+92 \%$; Fig. 5B; $P<0 \cdot 05$ ), higher IRI (twofold increase; Fig. 5C; $P<0 \cdot 05)$, and lower adiponectin/VFM ratio $(-39 \% ; P<0 \cdot 05$; Fig. $5 \mathrm{E})$, suggesting impairment in glucose homeostasis. All changes observed in the $\mathrm{N}$ group were normalized by dietary calcium supplementation for 2 months.
In the subcutaneous adipose tissue, calcium supplementation did not affect Sirt1 mRNA expression; however, $\mathrm{N}$ offspring showed lower Sirt1 mRNA levels in the visceral fat $(-37 \%, P<0.05$; Fig. 6A) and higher SIRT1 mRNA levels in the liver of $\mathrm{NCa}$ offspring $(+42 \% ; P<0.05$; Fig. 6B).

Absolute adrenal catecholamine content presented no significant difference between groups (Fig. 7A). N offspring showed higher relative adrenal catecholamine content $(+37 \%$; Fig. 7B; $P<0 \cdot 05)$ and higher $\mathrm{TH}$ expression $(+51 \%$; Fig. $7 \mathrm{C} ; P<0 \cdot 05)$. In NCa offspring, these changes were normalized.

As expected, maternal nicotine exposure programed for lower serum $\mathrm{tT}_{3}$ and $\mathrm{fT}_{4}$ levels when compared with $\mathrm{C}$ offspring ( -76 and $-74 \%$; Fig. $8 \mathrm{~A}$ and $\mathrm{B}$ respectively; $P<0 \cdot 05)$, accompanied by lower liver mGPD activity $(-54 \%$; Fig. 8C; $P<0 \cdot 05)$, an enzyme considered an important marker of thyroid status. These thyroid function parameters were not normalized in $\mathrm{NCa}$ offspring.

Lipid profile evaluation (TC, HDL, LDL, VLDL, TG, and Castelli indexes I and II) showed no significant difference between groups (Table 1).

\section{Discussion}

We have recently reported maternal nicotine exposure programs for higher central obesity and IR, two important parameters of the metabolic syndrome, in the adult progeny (Oliveira et al. 2010). The most remarkable finding of this study is that calcium supplementation for 2 months reverts, in adult rats, some of the metabolic disorders that were programed by nicotine exposure in early postnatal life.

Calcium carbonate was used instead of dairy products so as to isolate the effect of calcium, because dairy products contain

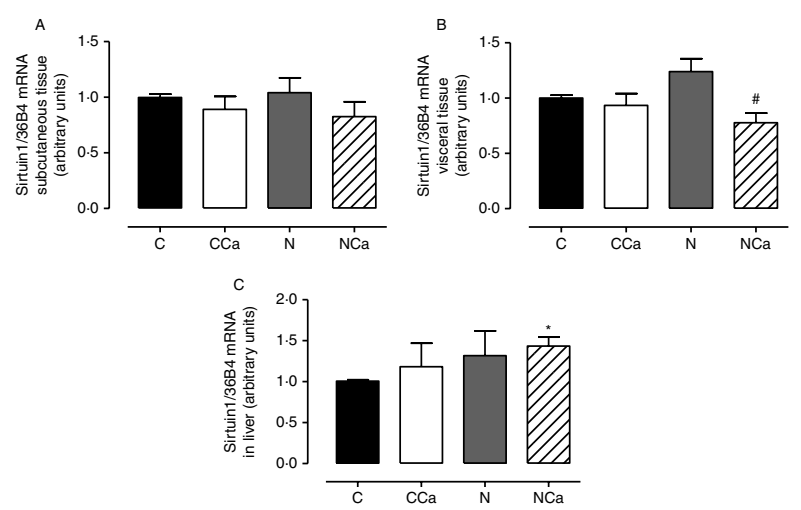

Figure 6 Sirtuin 1 mRNA expression 1 in subcutaneous (A) and visceral (B) adipose tissue and in the liver (C) of adult offspring whose mothers were exposed to nicotine or saline during lactation that were treated with dietary calcium supplement for 2 months. Values represent mean \pm s.E.M. of ten rats per group. ${ }^{*} P<0.05$ versus control $(\mathrm{C}),{ }^{\sharp} P<0 \cdot 05$ versus nicotine $(\mathrm{N})$. 

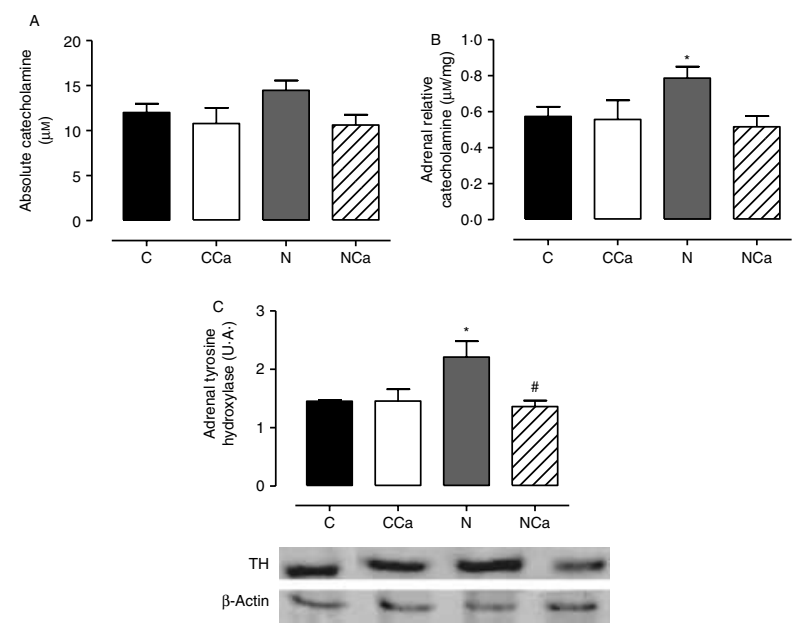

Figure 7 Total (A) and relative (B) catecholamine content and tyrosine hydroxylase $(\mathrm{TH})$ expression $(\mathrm{C})$ of adult offspring whose mothers were exposed to nicotine or saline during lactation that were treated with dietary calcium supplement for 2 months. Values represent mean \pm S.E.M. of ten rats per group. ${ }^{*} P<0 \cdot 05$ versus control $(C),{ }^{\sharp} P<0 \cdot 05$ versus nicotine $(N)$.

other substances, such as magnesium and leucine, which could have affected the interpretation of the present findings. Calcium dietary supplementation caused no increase in serum calcium levels but decreased serum 25-hydroxyvitamin $\mathrm{D}_{3}$ in the nicotine offspring to normal levels. The unchanged calcium serum levels could be expected due to very tight homeostatic mechanisms associated with the maintenance of adequate calcium concentration in the extracellular liquid, which are mainly performed by PTH and calcitriol (Potts 2005, Heaney 2006). Surprisingly, serum 25-hydroxyvitamin $\mathrm{D}_{3}$ was very high in $\mathrm{N}$ offspring, which were overweight, suggesting a role for excessive calcitriol in adipogenesis. The inhibition of these higher calcitriol levels probably reversed the higher adiposity. Also, this result shows that the calcium dose we used for obesity management was not toxic to the animals.

Our current data regarding higher visceral and total body fat contents, hyperleptinemia, hypothyroidism, IR, and leptin resistance in P180 offspring whose mothers were treated with nicotine during lactation corroborate our previous data (de Oliveira et al. 2010, Santos-Silva et al. 2010). Dietary calcium supplementation of adult $\mathrm{N}$ offspring was capable of normalizing central obesity, leptinemia, and insulin sensitivity. Obese transgenic rats expressing agouti protein that received a calcium-rich diet $(1 \cdot 2 \%$ calcium carbonate during 6 weeks) had lower weight gain and those who had a diet rich in dairy products had an even smaller gain. In humans, a significant decrease in abdominal obesity was observed with diets rich in calcium or dairy products (Zemel 2004). However, in another study using $1500 \mathrm{mg}$ calcium carbonate during 2 years, obese individuals did not show significant differences in BW gain (Yanovski et al. 2009).
The mechanisms induced by calcium supplementation that could explain abdominal obesity reduction remain unclear. It is possible that calcitriol plays a role in energy metabolism by regulating the deposition and expansion of local fat in adipose tissue. Besides, excessive deposition of central fat in obesity may be the result of a greater capacity for the regeneration of glucocorticoids in visceral fat depots (Zemel 2004, Zemel \& Sun 2008). Glucocorticoid levels in abdominal adipose tissue and the availability of intracellular glucocorticoids are controlled by the $11 \beta$-hydroxysteroid dehydrogenase- 1 (11 $\beta$-HSD-1) activity, which generates local active cortisol (or corticosterone, in rats) from cortisone. Obese individuals have increased mRNA of this enzyme in both subcutaneous and visceral fat tissues (Desbriere et al. 2006). Experimental studies (Masuzaki et al. 2001) have shown higher 11ß-HSD-1 gene expression in adipose tissue associated with features of metabolic syndrome such as increased waist circumference and IR. Calcitriol directly regulates local 11ß-HSD-1 expression and release of cortisol, indicating a potential role of calcitriol in visceral adiposity (Zemel 2003, Zemel \& Sun 2008) and calcium-rich diet inhibits calcitriol in rats, resulting in the inhibition of $11 \beta-H S D-1$ expression. In the adipocyte, calcitriol decreases mitochondrial UCP2 activity, apoptosis, and lipolysis and increases lipogenesis. So, the lower central obesity of $\mathrm{N}$ offspring induced by calcium supplementation can be attributed, at least in part, to the inhibition of calcitriol levels and cortisol generation by visceral adipocytes (Zemel \& Sun 2008). Another hypothesis for the anti-obesity effect of dietary calcium is related to its capacity to form an insoluble complex with lipids in the intestine, increasing lipid fecal excretion and consequently reducing absorption (Zemel 2002, Teegarden et al. 2008).

Calcium supplementation reduced leptin mRNA expression in visceral tissue and normalized serum leptin. These effects can be explained by the higher lipolysis and

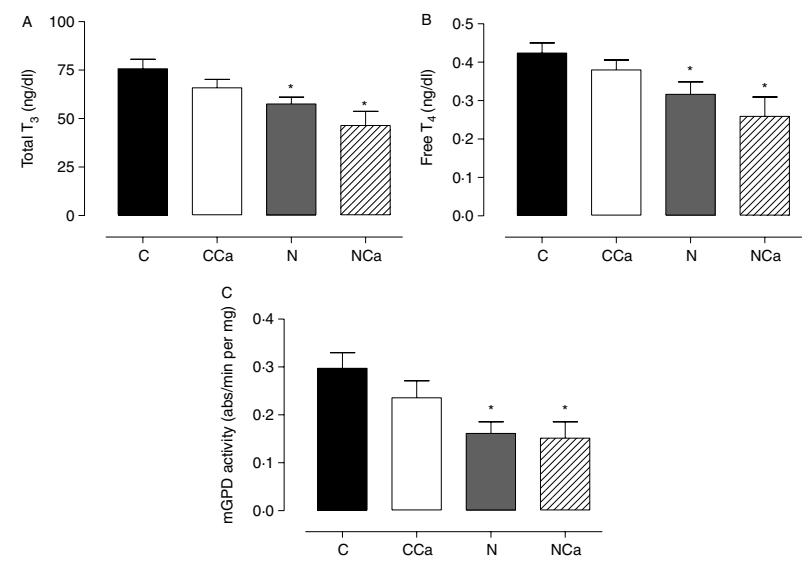

Figure 8 Serum total $T_{3}(A)$, serum-free $T_{4}(B)$, and liver mGPD activity $(\mathrm{C})$ of adult offspring whose mothers were exposed to nicotine or saline during lactation that were treated with dietary calcium supplement for 2 months. Values represent mean \pm s.E.M. of ten rats per group. ${ }^{*} P<0 \cdot 05$ versus control (C). 
Table 1 Lipid profile of adult offspring whose mothers were exposed to nicotine $(\mathrm{N})$ or saline $(\mathrm{C})$ during lactation that were treated with dietary calcium supplement for 2 months (CCa and $\mathrm{NCa}$ )

\begin{tabular}{|c|c|c|c|}
\hline C & $\mathrm{CCa}$ & $\mathbf{N}$ & $\mathrm{NCa}$ \\
\hline $63 \cdot 00 \pm 6 \cdot 03$ & $75 \cdot 25 \pm 3 \cdot 13$ & $65 \cdot 70 \pm 2 \cdot 10$ & $69 \cdot 33 \pm 3 \cdot 33$ \\
\hline $35.43 \pm 3.94$ & $40 \cdot 38 \pm 2 \cdot 04$ & $32 \cdot 20 \pm 2 \cdot 42$ & $30 \cdot 56 \pm 2.96$ \\
\hline $13 \cdot 00 \pm 12 \cdot 00$ & $11 \cdot 00 \pm 3.75$ & $15 \cdot 67 \pm 3 \cdot 89$ & $19 \cdot 57 \pm 5 \cdot 41$ \\
\hline $29 \cdot 00 \pm 5.93$ & $30.08 \pm 3.63$ & $27 \cdot 92 \pm 2 \cdot 34$ & $27 \cdot 67 \pm 4 \cdot 38$ \\
\hline $147 \cdot 00 \pm 29 \cdot 66$ & $150 \cdot 40 \pm 18 \cdot 14$ & $139 \cdot 60 \pm 11 \cdot 69$ & $138 \cdot 30 \pm 21 \cdot 90$ \\
\hline $1 \cdot 85 \pm 0 \cdot 20$ & $1 \cdot 90 \pm 0 \cdot 14$ & $2 \cdot 23 \pm 0 \cdot 29$ & $2 \cdot 48 \pm 0 \cdot 33$ \\
\hline $0.61 \pm 0.59$ & $0 \cdot 29 \pm 0 \cdot 12$ & $0 \cdot 85 \pm 0 \cdot 29$ & $0 \cdot 87 \pm 0 \cdot 31$ \\
\hline
\end{tabular}

HDL cholesterol, high-density lipoprotein cholesterol; LDL cholesterol, low-density lipoprotein cholesterol; VLDL cholesterol, very low-density lipoprotein cholesterol.

adipocyte apoptosis possibly induced by higher calcium intake. $\mathrm{N}$ offspring presented resistance to the anorexigenic effect of leptin caused by lower Ob-R expression in hypothalamus, as already published (de Oliveira et al. 2010), which was reversed by the calcium supplementation. As lower $\mathrm{Ob}-\mathrm{R}$ could be explained by a downregulatory effect of hyperleptinemia, the normalization of leptin levels with calcium also corrects hypothalamic Ob-R.

Concerning insulin sensitivity, the present finding confirms the impairment of glucose homeostasis previously observed in $\mathrm{N}$ offspring (de Oliveira et al. 2010) and showed that dietary calcium was successful in recovering this parameter. In fact, some epidemiological studies showed a negative association between calcium intake and glucose levels and insulin and IR (Sánchez et al. 1997, Davies et al. 2000, Pittas et al. 2007, Villegas et al. 2009).

Mechanisms that explain the role of calcium in IR are also not completely elucidated. Some studies suggest that the increase in intracellular calcium concentration can affect the transport of glucose mediated by insulin and insulin secretion (Zemel 1998, Tremblay \& Gilbert 2009). In rat and human adipocytes, high concentrations of intracellular calcium reduce insulin-mediated glucose transport (Draznin et al. 1988). Changes in intracellular calcium in target insulin tissues may contribute to changes in insulin action (Ojuka 2004, Pittas et al. 2007). The increase in intracellular calcium caused by hyperinsulinemia leads to IR (Begum et al. 1993). Calcitriol can increase intracellular calcium in these tissues and higher calcium intake can block this influx by inhibition of calcitriol. Thus, normal concentration of intracellular calcium is essential for insulin secretion by pancreatic $\beta$-cells as well as for insulin-mediated intracellular processes in tissues such as skeletal muscle and adipose tissue.

Low-calcium diet increases serum calcitriol, increasing intracellular calcium and, in part, this could result in IR in adipocytes and other insulin target cells mainly by phosphorylation of the glucose transporter type 4 (GLUT4), making insulin-mediated glucose uptake less efficient and promoting systemic IR (Reusch et al. 1991, Begum et al. 1993, Zemel et al. 1995, McCarty et al. 2002). In fact, $\mathrm{N}$ offspring presented lower serum 25-hydroxyvitamin $\mathrm{D}_{3}$ and IR.
The simplest mechanism that could explain the increase in insulin sensitivity with calcium therapy is related to the decrease in BW and adiposity. However, other more complex mechanisms may be involved. Increased SIRT1 activity has been associated with lower adiposity and protection from dietinduced metabolic disorders (Banks et al. 2008, Pfluger et al. 2008). In this sense, another possible mechanism that could correct the impairment in glucose homeostasis in $\mathrm{N}$ offspring with calcium supplementation is the change in expression of genes that regulate the metabolism, such as SIRT1. SIRT1 stimulates a glucose-dependent insulin secretion from pancreatic $\beta$-cells and directly stimulates insulin-signaling pathways in insulin-sensitive organs. Furthermore, SIRT1 regulates adiponectin secretion, gluconeogenesis, and reactive oxygen species levels, which together contribute to the development of IR. Moreover, SIRT1 overexpression and several SIRT1 activators have beneficial effects on glucose homeostasis and insulin sensitivity in obese mice models. We showed a higher liver SIRT1 expression in NCa offspring that may be potentially associated with the favorable metabolic phenotype observed in this group, such as the reduction in central obesity and improvement in insulin sensitivity. Surprisingly, NCa offspring displayed lower SIRT1 expression in visceral fat tissue. Perhaps lower leptin levels in $\mathrm{NCa}$ offspring are responsible for the lower SIRT1 expression in adipocyte, because leptin treatment in $o b / o b$ mice increases SIRT1 expression in white adipose tissue in a dose-dependent manner (Zhang et al. 2009).

This study, for the first time, shows that postnatal nicotine exposure programed for higher catecholamine levels and adrenal $\mathrm{TH}$ expression in adulthood, suggesting that $\mathrm{N}$ offspring developed higher catecholamine synthesis. Notably, leptin stimulates catecholamine synthesis and secretion (Trevenzoli et al. 2007), so the present findings may be due to the hyperleptinemia of $\mathrm{N}$ offspring. Calcium supplementation prevents adrenal medulla dysfunction in $\mathrm{N}$ offspring, possibly through the normalization of leptin levels. This result does not allow us to reach a conclusion about the effect of calcium supplementation on catecholamine action, because we did not measure serum catecholamine levels or its tissue action. 
We have previously shown that maternal nicotine exposure during lactation programs for secondary hypothyroidism in adult offspring (Oliveira et al. 2009). In this study, we also detected lower serum thyroid hormone levels as well as lower liver mGPD activity in $\mathrm{N}$ group, confirming our previous data. However, calcium supplementation did not correct the thyroid hypofunction observed in the $\mathrm{N}$ group. Thus, the normalization of visceral adiposity cannot be attributed to the normalization of the thyroid function.

It is important to consider that nicotine may have a priming effect in calcium metabolism and regulation during lactation with possible programming consequences in calcium hormonal regulation in adulthood, because nicotine administration in female rats results in lower serum calcitriol with no differences in serum $\mathrm{Ca}^{+}$or PTH (Iwaniec et al. 2002) and because serum cotinine (a nicotine metabolite) has a significant inverse relationship with bone mineral content in a clinical study (Benson \& Shulman 2005).

In conclusion, although the role of calcium on body fat is still controversial, calcium supplementation for 2 months reversed most of the alterations observed in adult obese rats programed by maternal nicotine exposure, such as increased visceral fat, which is a risk factor for IR, but did not correct the hypothyroidism development. Calciotropic hormones and lower intestinal fat absorption could be involved in the anti-obesity effect of calcium. Thus, a possible sequence of events after higher calcium intake is the inhibition of calcitriol with increases in lipolysis and apoptosis of adipocytes, which explain the lower VFM. The normalization of leptin and the increase in adiponectin are a result of less adipose tissue and both contribute to better insulin sensitivity. A calcium-rich diet seems to be an effective anti-obesity strategy, and perhaps, the reduction in fat mass per se, induced by calcium, is the main mechanism that leads to increased insulin action.

\section{Declaration of interest}

The authors declare that there is no conflict of interest that could be perceived as prejudicing the impartiality of the research reported.

\section{Funding}

This research was supported by the 'National Council for Scientific and Technological Development' (Conselho Nacional de Desenvolvimento Científico e Tecnológico-CNPq), the 'Carlos Chagas Filho Research Foundation of the State of Rio de Janeiro' (Fundação Carlos Chagas Filho de Amparo à Pesquisa do Estado do Rio de Janeiro-FAPERJ), and Coordination for the Enhancement of Higher Education Personnel (Coordenção de Aperfeiçoamento de Pessoal de Nível Superior - CAPES). $\mathrm{E} \mathrm{O}$ and $\mathrm{J} L \mathrm{~N}$ were recipients of the CAPES fellowship, A P S-S was recipient of a CNPq fellowship, and N S L was recipient of a FAPERJ fellowship.

\section{Acknowledgements}

All the authors are grateful to Antonio C M de Sá, Vania Pinto, and Ana Maria B coutinho from Laboratory of Lipids (LabLip, UERJ) for lipid profile determination. We also thank Miss Monica Moura and Luciano Santos for technical assistance.

\section{References}

Akamine R, Yamamoto T, Watanabe M, Yamazaki N, Kataoka M, Ishikawa M, Ooie T, Baba Y \& Shinohara Y 2007 Usefulness of the $5^{\prime}$ region of the cDNA encoding acidic ribosomal phosphoprotein $\mathrm{P} 0$ conserved among rats, mice and humans as a standard probe for gene expression analysis in different tissues and animal species. Journal of Biochemical and Biophysical Methods 70 481-486. (doi:10.1016/j.jbbm.2006.11.008)

Banks AS, Kon N, Knight C, Matsumoto M, Gutierrez-Juarez R, Rossetti L, Gu W \& Accili D 2008 SirT1 gain of function increases energy efficiency and prevents diabetes in mice. Cell Metabolism 8 333-341. (doi:10.1016/j. cmet.2008.08.014)

Barker DJ 2003 The developmental origins of adult disease. European Journal of Epidemiology 18 733-736. (doi:10.1023/A:1025388901248)

Begum N, Leitner W, Reusch JE, Sussman KE \& Drazni B 1993 Glut-4 phosphorylation and its intrinsic activity - mechanism of $\mathrm{Ca}^{2+}$-induced inhibition of insulin-stimulated glucose transport. Journal of Biological Chemistry 268 3352-3356.

Benson BW \& Shulman JD 2005 Inclusion of tobacco exposure as a predictive factor for decreased bone mineral content. Nicotine \& Tobacco Research: Official Journal of the Society for Research on Nicotine and Tobacco 7 719-724. (doi:10.1080/14622200500259119)

Bergmann KE, Bergmann RL, Von Kries R, Bohm O, Richter R, Dudenhausen JW \& Wahn U 2003 Early determinants of childhood overweight and adiposity in a birth cohort study: role of breast-feeding. International Journal of Obesity and Related Metabolic Disorders 27 162-172. (doi:10.1038/sj.ijo.802200)

Blake KV, Gurrin LC, Evans SF, Beilin LJ, Landau LI, Stanley FJ \& Newnham JP 2000 Maternal cigarette smoking during pregnancy, low birth weight and subsequent blood pressure in early childhood. Early Human Development 57 137-147. (doi:10.1016/S0378-3782(99)00064-X)

Bradford MM 1976 A rapid and sensitive method for the quantitation of microgram quantities of protein utilizing the principle of protein-dye binding. Analytical Biochemistry 72 248-254. (doi:10.1016/00032697(76)90527-3)

Chen J, Dohi S, Tan Z, Banno Y \& Nozawa Y 2002 The inhibitory effect of local anesthetics on bradykinin-induced phospholipase $\mathrm{D}$ activation in rat pheochromocytoma PC12 cells. Anesthesia and Analgesia 95 88-97. (doi:10.1097/00000539-200207000-00016)

Choi HK, Willett WC, Stampfer MJ, Rimm E \& Hu F 2005 Dairy consumption and risk of type 2 diabetes mellitus in men - a prospective study. Archives of Internal Medicine 165 997-1003. (doi:10.1001/archinte. 165.9.997)

Davies KM, Heaney RP, Recker RR, Lappe JM, Barger-Lux MJ, Rafferty K \& Hinders S 2000 Calcium intake and body weight. Journal of Clinical Endocrinology and Metabolism 85 4635-4638. (doi:10. $1210 /$ jc. 85.12 .4635$)$

Desbriere R, Vuaroqueaux V, Achard V, Boullu-Ciocca S, Labuhn M, Dutour A \& Grino M 2006 11beta-Hydroxysteroid dehydrogenase type 1 mRNA is increased in both visceral and subcutaneous adipose tissue of obese patients. Obesity 14 794-798. (doi:10.1038/oby.2006.92)

Divers WA Jr, Wilkes MM, Babaknia A \& Yen SS 1981 Maternal smoking and elevation of catecholamines and metabolites in the amniotic fluid. American Journal of Obstetrics and Gynecology 141 625-628.

Draznin B, Sussman KE, Eckel RH, Kao M, Yost T \& Sherman NA 1988 Possible role of cytosolic free calcium concentrations in mediating insulin resistance of obesity and hyperinsulinemia. Journal of Clinical Investigation $\mathbf{8 2}$ 1848-1852. (doi:10.1172/JCI113801)

Elliott PJ \& Jirousek M 2008 Sirtuins: novel targets for metabolic disease. Current Opinion in Investigational Drugs 9 371-378.

Fagundes AT, Moura EG \& Passos MCF 2007 Maternal low-protein diet during lactation programmes body composition and glucose homeostasis in the adult rat offspring. British Journal of Nutrition 98 922-928. (doi:10.1017/ S0007114507750924)

Franco JG, de Moura EG, Koury JC, Trotta PA, Cordeiro A, Souza LL, Almeida NA, Lima Nda S, Pazos-Moura CC, Lisboa PC et al. 2010 
Resveratrol reduces lipid peroxidation and increases sirtuin 1 expression in adult animals programmed by neonatal protein restriction. Journal of Endocrinology 207 319-328. (doi:10.1677/JOE-10-0124)

Goldani MZ, Haeffner LSB, Agranonik M, Barbieri MA, Bettiol H \& Silva AAM 2007 Do early life factors influence body mass index in adolescents? Brazilian Journal of Medical and Biological Research $\mathbf{4 0}$ 1231-1236. (doi:10.1590/S0100-879X2006005000131)

Heaney RP 2006 Vitamin D - the iceberg nutrient. Journal of Musculoskeletal and Neuronal Interactions 6 334-335.

Iwaniec UT, Haynatzki GR, Fung YK, Akhter MP, Haven MC \& Cullen DM 2002 Effects of nicotine on bone and calciotropic hormones in aged ovariectomized rats. Journal of Musculoskeletal and Neuronal Interactions 2 469-478.

Jacqmain M, Doucet E, Despres JP, Bouchard C \& Tremblay A 2003 Calcium intake, body composition, and lipoprotein-lipid concentrations in adults. American Journal of Clinical Nutrition 77 1448-1452.

Kosti RI \& Panagiotakos DB 2006 The epidemic of obesity in children and adolescents in the world. Central European Journal of Public Health $\mathbf{1 4}$ 151-159.

Liang F, Kume S \& Koya D 2009 SIRT1 and insulin resistance. Nature Reviews. Endocrinology 5 367-373. (doi:10.1038/nrendo.2009.101)

Lichtensteiger W, Ribary U, Schlumpf M, Odermatt B \& Widmer HR 1988 Prenatal adverse effects of nicotine on the developing brain. Progress in Brain Research 73 137-157. (doi:10.1016/S0079-6123(08)60502-6)

Ma B, Lawson AB, Liese AD, Bell RA \& Mayer-Davis EJ 2006 Dairy, magnesium, and calcium intake in relation to insulin sensitivity: approaches to modeling a dose-dependent association. American Journal of Epidemiology 164 449-458. (doi:10.1093/aje/kwj246)

Machado DS, Sabeta A, Santiago LA, Sidhaye AR, Chiamolera MI, Ortiga-Carvalho TM \& Wondisford FE 2009 A thyroid hormone receptor mutation that dissociates thyroid hormone regulation of gene expression in vivo. PNAS 106 9441-9446. (doi:10.1073/pnas.0903227106)

Marques RG, Morales MM \& Petroianu A 2009 Brazilian law for scientific use of animals. Acta Cirúrgica Brasileira 24 69-74. (doi:10.1590/S010286502009000100015)

Masuzaki H, Paterson J, Shinyama H, Morton NM, Mullins JJ, Seckl JR \& Flier JS 2001 A transgenic model of visceral obesity and the metabolic syndrome. Science 294 2166-2170. (doi:10.1126/science.1066285)

McBride CM \& Pirie PL 1990 Postpartum smoking relapse. Addictive behaviors 15 165-168.

McCarty MF, Merzer G, Pereira MA \& Ludwig DS 2002 Dairy products and insulin resistance. The Journal of the American Medical Association 288 693-694.

Moura EG \& Passos MC 2005 Neonatal programming of body weight regulation and energetic metabolism. Bioscience Reports 25 251-269. (doi:10.1007/s10540-005-2888-3)

de Moura EG, Lisboa PC \& Passos MC 2008 Neonatal programming of neuroimmunomodulation - role of adipocytokines and neuropeptides. Neuroimmunomodulation 15 176-188. (doi:10.1159/000153422)

Newbold RR 2010 Impact of environmental endocrine disrupting chemicals on the development of obesity. Hormones 9 206-217.

Ojuka EO 2004 Role of calcium and AMP kinase in the regulation of mitochondrial biogenesis and GLUT4 levels in muscle. Proceedings of the Nutrition Society 63 275-278. (doi:10.1079/PNS2004339)

Oliveira E, Fagundes AT, Alves SB, Pazos-Moura CC, Moura EG, Passos MC \& Lisboa PC 2007 Chronic leptin treatment inhibits liver mitochondrial alpha-glycerol-beta-phosphate dehydrogenase in euthyroid rats. Hormone and Metabolic Research 39 867-870. (doi:10.1055/s-2007-992131)

Oliveira E, Moura EG, Santos-Silva AP, Fagundes AT, Rios AS, Abreu-Villaça Y, Nogueira Neto JF, Passos MC \& Lisboa PC 2009 Short- and long-term effects of maternal nicotine exposure during lactation on body adiposity, lipid profile, and thyroid function of rat offspring. Journal of Endocrinology 202 397-405. (doi:10.1677/JOE-09-0020)

Oliveira E, Pinheiro CR, Santos-Silva AP, Trevenzoli IH, Abreu-Villaça Y, Nogueira Neto JF, Reis AM, Passos MC, Moura EG \& Lisboa PC 2010 Nicotine exposure effects mother's and pup's nutriotional, biochemical and hormonal profile during lactation in rats. Journal of Endocrinology 205 159-170. (doi:10.1677/JOE-09-0430) de Oliveira E, Moura EG, Santos-Silva AP, Pinheiro CR, Lima NS, Nogueira-Neto JF, Nunes-Freitas AL, Abreu-Villaça Y, Passos MCF \& Lisboa PC 2010 Neonatal nicotine exposure causes insulin and leptin resistance and inhibits hypothalamic leptin signaling in adult rat offspring. Journal of Endocrinology 206 55-63. (doi:10.1677/JOE-10-0104)

Paula GS, Souza LL, Cabanelas A, Bloise FF, Mello-Coelho V, Wada E, Ortiga-Carvalho TM, Oliveira KJ \& Pazos-Moura CC 2010 Female mice target deleted for the neuromedin $\mathrm{B}$ receptor have partial resistance to dietinduced obesity. Journal of Physiology 1 1635-1645. (doi:10.1113/jphysiol. 2009.185322)

Pfluger PT, Herranz D, Velasco-Miguel S, Serrano M \& Tschöp MH 2008 Sirt1 protects against high-fat diet-induced metabolic damage. PNAS 105 9793-9798. (doi:10.1073/pnas.0802917105)

Pittas AG, Harris SS, Stark PC \& Dawson-Hughes B 2007 The effects of calcium and vitamin D supplementation on blood glucose and markers of inflammation in nondiabetic adults. Diabetes Care 30 980-986. (doi:10. 2337/dc06-1994)

Potts JT 2005 Parathyroid hormone: past and present. Journal of Endocrinology 187 311-325. (doi:10.1677/joe.1.06057)

Rajendrasozhan S, Yang SR, Kinnula VL \& Rahman I 2008 SIRT1, an antiinflammatory and antiaging protein, is decreased in lungs of patients with chronic obstructive pulmonary disease. American Journal of Respiratory and Critical Care Medicine 177 861-870. (doi:10.1164/rccm.2007081269OC)

Reeves PG 1997 Components of the AIN-93 diets as improvements in the AIN-76A diet. The Journal of Nutrition 127 838S-841S.

Reid IR, Ames R, Mason B, Bolland MJ, Bacon CJ, Reid HE, Kyle C, Gamble GD, Grey A \& Horne A 2010 Effects of calcium supplementation on lipids, blood pressure, and body composition in healthy older men: a randomized controlled trial. American Journal of Clinical Nutrition 91 131-139. (doi:10.3945/ajcn.2009.28097)

Reusch JEB, Begum N, Sussman KE \& Draznin B 1991 Regulation of GLUT-4 phosphorylation by intracellular calcium in adipocytes. Endocrinology 129 3269-3273. (doi:10.1210/endo-129-6-3269)

Rodgers JT, Lerin C, Haas W, Gygi SP, Spiegelman BM \& Puigserver P 2005 Nutrient control of glucose homeostatis through a complex of PGC-1a and SIRT-1. Nature 434 113-118. (doi:10.1038/nature03354)

Sánchez M, de la Sierra A, Coca A, Poch E, Gmer V \& Urbano-Mfirquez A 1997 Oral calcium supplementation reduces intraplatelet free calcium concentration and insulin resistance in essential hypertensive patients. Hypertension 29 531-536. (doi:10.1161/01.HYP.29.1.531)

Santos-Silva AP, Moura EG, Pinheiro CR, Rios AS, Abreu-Villaça Y, Passos MC, Oliveira E \& Lisboa PC 2010 Neonatal nicotine exposure alters leptin signaling in the hypothalamus-pituitary-thyroid axis in the late postnatal period and adulthood in rats. Life Sciences 87 187-195. (doi:10.1016/j.lfs. 2010.06.012)

Schulze MB, Rimm EB, Shai I, Rifai N \& Hu FB 2004 Relationship between adiponectin and glycemic control, blood lipids, and inflammatory markers in men with type 2 diabetes. Diabetes Care 27 1680-1687. (doi:10.2337/ diacare.27.7.1680)

Teegarden D, White KM, Lyle RM, Zemel MB \& Van Loan MD 2008 Calcium and dairy product modulation of lipid utilization and energy expenditure. Obesity 16 1566-1572. (doi:10.1038/oby.2008.232)

Toste FP, Alves SB, Dutra SCP, Bonomo IT, Lisboa PC, Moura EG \& Passos MCF 2006a Temporal evaluation of the thyroid function of rats programed by leptin treatment on the neonatal period. Hormone and Metabolic Research 38 827-831. (doi:10.1055/s-2006-956502)

Toste FP, de Moura EG, Lisboa PC, Fagundes AT, de Oliveira E \& Passos MC $2006 b$ Neonatal leptin treatment programmes leptin hypothalamic resistance and intermediary metabolic parameters in adult rats. British Journal of Nutrition 95 830-837. (doi:10.1079/BJN20061726)

Tremblay A \& Gilbert JA 2009 Milk products, insulin resistance syndrome and type 2 diabetes. Journal of the American College of Nutrition 28 91S-102S.

Trevenzoli IH, Valle MMR, Machado FB, Garcia RMG, Passos MCF, Lisboa PC \& Moura EG 2007 Neonatal hyperleptinaemia programmes adrenal medullary function in adult rats: effects on cardiovascular parameters. Journal of Physiology 580 629-637. (doi:10.1113/jphysiol.2006.126151) 
Trotta PA, Moura EG, Franco JG, Lima NS, de Oliveira E, Cordeiro A, Souza LL, Oliveira KJ, Lisboa PC, Pazos Moura CC et al. 2011 Blocking leptin action one week after weaning reverts most of the programming caused by neonatal hyperleptinemia in the adult rat. Hormone and Metabolic Research 43 171-177. (doi:10.1055/s-0031-1271694)

Villegas R, Gao Y, Dai Q, Yang G, Cai H, Li H, Zheng W \& Shu XO 2009 Dietary calcium and magnesium intakes and the risk of type 2 diabetes: the Shanghai Women's Health Study. American Journal of Clinical Nutrition 89 1059-1067. (doi:10.3945/ajcn.2008.27182)

Warner JJ 2001 Major divisions of the cerebral hemispheres demonstrated on references sections. In Atlas of Neuroanatomy: With Systems Organization and Case Correlations, edn 1, pp 65-71. Oxford: Butterworth-Heinemann.

Weiss R, Dziura J, Burgert TS, Tamborlane WV, Taksali SE, Yeckel CW, Allen K, Lopes M, Savoye M, Morrison J et al. 2004 Obesity and the metabolic syndrome in children and adolescents. New England Journal of Medicine $\mathbf{3 5 0}$ 2362-2374. (doi:10.1056/NEJMoa031049)

Xiaoyu Z, Payal B, Melissa O \& Zanello LP 2007 1 $\alpha, 25(\mathrm{OH}) 2-$ Vitamin $\mathrm{D}_{3}$ membrane-initiated calcium signaling modulates exocytosis and cell survival. Journal of Steroid Biochemistry and Molecular Biology 103 457-461. (doi:10.1016/j.jsbmb.2006.11.002)

Yanovski JA, Parikh SJ, Yanoff LB, Denkinger BI, Calis KA, Reynolds JC, Sebring NG \& McHugh T 2009 Effects of calcium supplementation on body weight and adiposity in overweight and obese adults - a randomized trial. Annals of Internal Medicine 150 821-829.

Zemel MB 1998 Nutritional and endocrine modulation of intracellularcalcium: implications in obesity, insulin resistance and hypertension. Molecular and Cellular Biochemistry 188 129-136. (doi:10.1023/A:1006880708475)
Zemel MB 2002 Regulation of adiposity and obesity risk by dietary calcium: mechanisms and implications. Journal of the American College of Nutrition 21 146S-151S.

Zemel MB 2003 Role of dietary calcium and dairy products in modulating adiposity. Lipids 38 139-146. (doi:10.1007/s11745-003-1044-6)

Zemel MB 2004 Role of calcium and dairy products in energy partitioning and weight management. American Journal of Clinical Nutrition 79 907S-912S.

Zemel MB 2005 The role of dairy foods in weight management. Journal of the American College of Nutrition 24 S537-S546.

Zemel MB \& Sun X 2008 Dietary calcium and dairy products modulate oxidative and inflammatory stress in mice and humans. Journal of Nutrition 138 1047-1052.

Zemel MB, Kim JH, Woychik RP, Michaud EJ, Kadwell SH, Patel IR \& Wilkison WO 1995 Agouti regulation of intracellular calcium: role in the insulin resistance of viable yellow mice. PNAS 92 4733-4737. (doi:10.1073/pnas.92.11.4733)

Zhang Y, Zhang M, Dong H, Yong S, Li X, Olashaw N, Kruk PA, Cheng JQ, Bai W, Chen J, Nicosia SV \& Zhang X 2009 Deacetylation of cortactin by SIRT1 promotes cell migration. Oncogene 28 445-460.

Received in final form 6 June 2011

Accepted 16 June 2011

Made available online as an Accepted Preprint 16 June 2011 